\title{
Influence of Almajirci on School Attendance and Academic Performance among Students of Almajiri Integrated Model School, Sokoto State
}

\author{
Binta Garba Abubakar ${ }^{1} \&$ Joy N. Njoku ${ }^{2, *}$ \\ ${ }^{1}$ Ahmadu Bello Academy Farfaru Sokoto, Sokoto State, Nigeria \\ ${ }^{2}$ Department of Educational Foundations Guidance \& Counselling, Faculty of Education, University of Calabar, \\ Cross River State, Nigeria \\ *Correspondence: Department of Educational Foundations Guidance \& Counselling, Faculty of Education, \\ University of Calabar, Cross River State, Nigeria. Tel: 234-803-547-3928. E-mail: jnnjoku3@gmail.com
}

Received: May 21, 2015

doi:10.5430/wje.v5n4p58
Accepted: July 10, $2015 \quad$ Online Published: July 20, 2015

URL: http://dx.doi.org/10.5430/wje.v5n4p58

\begin{abstract}
This study investigated the influence of Almajirci, on School Attendance and Academic performance Among Students of Almajiri Integrated Model School, Sokoto State. The sample size used was Three hundred and six Junior Secondary School students of Almajiri Integrated Model School Sokoto and Sultan Bello Secondary School Sokoto. Students of Almajiri Integrated Model School had almajiri experience while those in Sultan Bello did not. Two null hypotheses were formulated and analysed using frequency distribution table, percentages and ANOVA. Two instruments were used for data collection. They are Questionnaire investigating influence of almajirici on school attendance and Academic Performance Test in English language, Mathematics, Arabic and Islamic Studies. The results revealed that there is no influence of almajirci practice on the school attendance of students of Almajiri Integrated School. However, there was significant difference between the academic performance of students of Almajiri Integrated Model School Sokoto and Sultan Bello Junior Secondary School, Sokoto in favour of students of Sultan Bello Junior Secondary School. It is therefore recommended that parents and the society in general should support the government initiative effort by ensuring that children are enrolled into secular schools early enough and all almajirai are enrolled into Almajiri Integrated Model School Sokoto for all round education.
\end{abstract}

Keywords: Influence, Almajirci, School Attendance, Academic Performance, Students

\section{Introduction}

The word 'Almajirci' is derived from the Arabic word 'Almuhajirun' migrants. It refers to a traditional method of acquiring and memorizing the Glorious Qur'an in Hausa/Fulani community where boys at their tender ages are sent out by their parents, guardians, or relations to relatively far away villages, towns and cities for Qur'anic education under a knowledgeable Islamic scholar called Mallam. In pre-colonial era especially after the jihad of Usman DanFodio, Almajirci was widely practiced in the Northern part of Nigeria. Usually at the end of the harvest season, Qur'anic teachers gather children, aged six to twelve, with the consent of their parents, from a village or group of neighbouring villages, and travel with them to an urban centre. The target urban centers then were Sokoto, Kano, Katsina, Borno, Bauchi, Damagaran and other Hausa cities (Auwal, 1992).

The significant point here is that, during this period, the pupils under their Mallams devoted the largest proportion of their time to learning the Quran. All other activities were considered as secondary to memorization of Quran and other facets of Islamic education. The principle behind sending young children to distant places in order to learn was based on the idea of discipline. It was believed then that children would learn better and quicker when kept away from parental care and house chores. Parents further believed that sending their children with itinerant Mallams to distant places instilled the love for Islamic education in the minds of the children and it gave them a solid foundation in basic education as well as acquisition of life skills through manual labour (Auwal, 1992).

Almajirci in its contemporary form has undergone radical transformation as a result of changing society. As a result of these changes, Almajirci has entirely lost its education/religious relevance and has become nothing more than a malevolent monstrous and exploitative economic enterprise (Auwal, 1992). In order to reduce the burden of almajirai 
and introduce them to Western Education without jeopardizing their interest in Quranic studies, integration became imperative. The concept of integration was to join elements of basic education that is, western type of education, together with traditional Qur'anic school systems without interfering with the goals of the Qur'anic school system. It was to strengthen the ability of the learners to read, write and memorise the Qur;an in a conducive learning atmosphere and to introduce secular subjects of education into Qur'anic school system thereby making the products literate, numerate and to enable them acquire manipulative and survival skills in the modern formal system. It was also to eradicate almajirci method of involving teenage children in street begging, hard labour, unhygienic condition, social vices and also to provide adequate and qualitative instructional materials in both Islamic and secular subjects. (Sule, 2002).

Various efforts had been made over the years by groups, individuals, organisations and governments towards a successful integration of the Qur'anic school or Islamic education into the Western Education System, such attempts had achieved varying degrees of success. What is required is to strengthen and build upon them. The Sokoto State Government under the Ministry for Islamic Affairs was not left out on the establishment of Almajiri Integrated Model School. The institution was established in the year 2008 to curtail the menace of street begging by children and youth in the name of pursuing Qur'anic education. Many of the almajirai enrolled in the Integrated Model Schools are orphans and vulnerable children selected from the (Makarantar Allo) which is the Traditional Qura'nic Boarding Schools.

It may take a long time before the students of Almajiri Integrated Model School Sokoto would compete favourably with students in secular schools in subjects like English language. According to the findings of Mubarak, M., Bargaja I. M., Aishatu. M. A., Hauwau A. A. and Shafa'atu. U.T. (2012) who conducted a research on the problems and prospects of Almajiri Integrated School Sokoto, their study revealed that though the school had qualified teachers who are graduates, the major problems faced by the students was the difficulties in the understanding of English language which is the language of communication in the classroom.

People like Mahuta (2009), Bunza (2009) and Dahiru (2011) declared that the aims and objectives of integrating the two systems of education among others were:

a. To integrate elements of Basic Education into the Qur'anic school system without interfering with the goals of the Qur'anic system. These shall be with the view to improve their capacities and empowering them.

b. To increase the number of school enrolment thereby greatly reducing the number of out of school children on the streets and to improve the health condition of the Qur'anic or Almajirci school children.

This paper therefore examined the influence of almajirci on school attendance and academic performance among students of Almajiri Integrated School, Sokoto.

\section{Statement of the Problem}

The Federal Republic of Nigeria (2004) National Policy on Education provided for equal opportunity for education for all Nigerian children irrespective of tribe, religion or disability but many children in Northern Nigeria did not enjoy this privilege due to their religious beliefs . Their parent exposed them to only Quranic education where they learn how to recite the Quran and some handwork. They were not taught how to read and write in English Language which is the Lingua franca. They grew up with negative attitude to Western Education. However the almajiri system of education evolved with good intention, meant to groom young children in Islamic and cultural beliefs and conducts, and it was serving a good purpose, but nowadays the Almajirci system has turned almajirai (pupils) to be tools for money making in the hands of Mallams. Some are even required to give a fixed amount on daily basis, feed themselves and cloth themselves. This makes them to always roam about at motor parks, from house to house, from street to street and to other public places begging for money and food. They get exposed to diseases and all kinds of danger. They enter prohibited places. This led some of the almajirai of makarantanallo (traditional Qur'anic schools) to intermingle with bad people, engage in bad conducts like stealing, fighting or being mobilised by some people to promote violence in the society for money. Before the establishment of Almajiri Integrated Model School attitude of many almajirai to school was very poor. This created doubts in the heart of many for the expected success of the students because attitude of students to schools according to some researchers like Njoku and Idoko (2012) who worked on the attitude of the girl-child to school and its effect on their academic performance in Sokoto state, Nigeria came up with the result that attitude to school can have positive or negative effect on performance. The almajirai were considered to be very comfortable with their life of roaming about the streets begging for food and money so some people felt that subjecting them to Western Education may be a waste of time and resources. These 
almajirai form the bulk of the population of Almajiri Integrated Model School, Sokoto. There was fear that the experiences of these children and their past activities may have negative effect on their school attendance and academic performance. This informed the need to investigate the influence of almajirci on school attendance and academic performance of students of Almajiri Integrated Model School, Sokoto State.

\section{Objectives of the Study}

The following were the objectives of the study:

i. To find out if Almajirci practices had any influence on the school attendance of students of Almajiri Integrated School Sokoto.

ii. To find out the difference between the performance of students of Almajiri Integrated Model School and Sultan Bello Junior Secondary School in English language, Mathematics, Arabic language and Islamic studies.

\section{Research Questions}

The study sought to answer the following research questions:

i. Is there any influence of Almajirci practices on the' school attendance of students of Almajiri Integrated School Sokoto?

ii. Is there any difference between the performance of students of Almajiri Integrated Model School Sokoto and Sultan Bello Junior Secondary School Sokoto in English language, Mathematics, Arabic language and Islamic studies?

\section{Research Hypotheses}

The research hypotheses are stated as:

i. There is no significant influence of Almajirci practices on the school attendance of students of Almajiri Integrated Model School Sokoto.

ii. There is no significant difference between the performance of students of Almajiri Integrated Model School Sokoto and Sultan Bello Junior Secondary School Sokoto in English language, Mathematics, Arabic language and Islamic studies.

\section{Methodology}

\subsection{Research Design}

A descriptive survey design was employed for this study. A Descriptive survey design is a type of research which involves the collection of data through development of questionnaires or other instruments (Salawu, 1991). It can be used to sample the opinion of many people at the same time.

\subsection{Population of the Study}

The population for this study covers all the JSS students of Almagiri Integrated Model School Sokoto and Junior Secondary School (JSS) students of Sultan Bello Secondary School Sokoto. There were a total number of 625 students at Almagiri Integrated Model School, Sokoto while the total number of JSS students in Sultan Bello Secondary School Sokoto was 875 . The total number of students from the two schools is 1,500 which constituted the population for the study.

\subsection{Sample and Sampling Techniques}

The sample size for the study was 306 students, made up of 153 students from Almajiri Integrated Model School Sokoto and 153 students from Sultan Bello Secondary School, Sokoto. The students were randomly selected from the two schools through the use of lucky dip approach. All the students in JSS III were given equal opportunity to participate. Those who picked "YES" were selected.

\subsection{Research Instruments}

Two instruments used to obtain relevant information for this study were; Questionnaire on Influence of Almajirci on school attendance and Academic Performance Test in English language, Mathematics, Arabic language and Islamic Studies. Experts in Educational Psychology and subject teachers validated the instruments. The test items were drawn from the students text books based on their syllabus. The teachers affirmed a high content validity of the test 
items. The items were subjected to a pilot study using 20 randomly selected students from Hafsatu Memorial Arabic Secondary School. A reliability coefficient of 0.70 was obtained using the test- retest method.

\subsection{Method of Data Collection}

The questionnaire investigating school attendance was the first to be administered to the selected students from Almajiri Integrated Model School, Sokoto. This was followed by academic performance test which was administered to students of both schools. The scripts were collected and marked.The results were subjected to analysis.

\subsection{Data Analysis}

Data was analysed using frequency distribution table, percentages and ANOVA.

\section{Results}

\subsection{Influence of Almajirci on School Attendance of Students of Almajiri Integrated Model School Sokoto}

The results of the school attendance questionnaire showed that almajirci has no influence on school attendance of the students of Almajiri Integrated Model School. The majority of the respondents 147(96.1) and 146(95.4) were both regular and punctual at school and as well attended lessons regularly. This implies that almajirci practices had no effect on the students' school attendance. Therefore the hypothesis is accepted.

Table 1. Influence of Almajirci Practices on the Students' School Attendance

\begin{tabular}{lcc}
\hline School Attendance & Yes & No \\
\hline Regular and punctual at School & $147(96.1 \%)$ & $6(3.9 \%)$ \\
Attend Classroom Lesson regularly & $146(95.4)$ & $7(4.6 \%)$ \\
\hline
\end{tabular}

Source: Research Field Work 2013

Hypothesis 2: There is no significant difference between the performance of students from Almajiri Integrated Model School and Sultan Bello Junior Secondary School in secular and Islamic related subjects.

Table 2. ANOVA Table Comparing the Differences between the Performance of Students from Almajiri Integrated School and Sultan Bello Junior Secondary School in English language, Mathematics, Arabic Language and Islamic Studies

\begin{tabular}{|c|c|c|c|c|c|c|c|}
\hline Variables & Subject & $\mathrm{N}$ & $\mathrm{X}$ & Std Dev & $. F-c a l$ & $P$-Value & Remarks \\
\hline Almajiri $\quad$ Integrated & English & 153 & 57.91 & 23.018 & \multirow{8}{*}{51.613} & \multirow{8}{*}{0.000} & \multirow{8}{*}{ Significant } \\
\hline Model School, Shuni & Math & 153 & 76.27 & 10.380 & & & \\
\hline \multirow{2}{*}{ Sokoto } & Islamic & 153 & 79.67 & 20.014 & & & \\
\hline & Arabic & 153 & 75.80 & 18.613 & & & \\
\hline SultanBello & English & 153 & 67.45 & 17.753 & & & \\
\hline Secondary & Math & 153 & 79.48 & 16.455 & & & \\
\hline \multirow[t]{2}{*}{ Sokoto } & Islamic & 153 & 66.59 & 14.003 & & & \\
\hline & Arabic & 153 & 90.57 & 14.482 & & & \\
\hline
\end{tabular}

Source: Research Field Work 2013

Using the ANOVA to test the hypothesis above, the results showed the values of F-cal and P-Value as 51.613 and 0.000 respectively. Since P-value (0.000) at 0.05 level of significance is less than Fcal (51.613) it implies that there was significant difference between the performance of students from Almajiri Integrated Model School and Sultan Bello Junior Secondary School in English language, Mathematics, Arabic language and Islamic studies.

This was further highlighted from the mean score in the various subjects for each of the schools. In English Language, Maths and Arabic Language, the mean scores for Sultan Bello Junior Secondary School students were 67.45, 79.48 and 90.57 respectively while those of students from Almajiri Integrated Model School were 57.91, 76.27 and 75.80 respectively. This showed that students of Sultan Bello Junior Secondary School scored higher in English language, Mathematics and Arabic studies, while in Islamic Studies the mean score for Almajiri Integrated Model School students was 79.67 compare to that of students of Sultan Bello Junior Secondary School which was 66.59, this implies that students of Almajiri Integrated Model School performed better in Islamic studies. 


\subsection{Summary of Major Findings}

The findings of the study revealed that there is no influence of almajrci practices on school attendance. But there was significant difference between the performance of students of Almajiri Integrated Model School, Sokoto and Sultan Bello Junior Secondary School, Sokoto. This difference was in favour of Sultan Bello Secondary school students in English language, Mathematics and Arabic language while Almajiri Integrated Model School students performed better in Islamic studies.

\section{Discussion of Findings}

The first hypothesis found no influence of Almajirci practices on the students' school attendance. The aims and objectives of integration according to Bunza(2009), Mahuta(2009) and Dahiru(2011) were to increase school enrolment and attendance of Almajirai to school. This result showed that this aim is being achieved. This will greatly reduce the number of out school children who roam about the streets. Parents should willingly embrace this government's initiative and send their boy-child to school for holistic education. The result here showed that if children are properly guided they will like to go to school. Also the result of the second hypothesis revealed that there was significant difference between the performance of students of Almajiri Integrated Model School and Sultan Bello Junior Secondary School in English language, Mathematics and Arabic language.This is in line with the findings of Mubarak, Bargaja, Aishatu, Hauwau, and Shafa'atu (2012) whose study revealed that one of the major problems faced by the students of Almajiri Intergraded Model School, Sokoto is the difficulty in the understanding of English language which is the general language of communication in the classroom. However the integration of western education with the traditional Quranic system is to improve students' academic performance. Most students of Almajiri Integrated Model School still performed better in Islamic studies which shows that if they get properly adjusted to Western Education they will also do well. The idea of integration of Western and Islamic education will better equip the students to face life challenges. Much attention should be given to secular subjects in the school.

\section{Conclusion}

Based on the findings of this study, it is therefore concluded that almajirci practices have no influence on the students' school attendance but it has on academic performance. Therefore there is the need for students of Almajiri Integrated Model School to improve more on the secular subjects.

\section{Recommendations}

1. Parents and the society in general should support the government initiative by ensuring that all almajirai are enrolled at Almajiri Integrated Model School. The students should also be monitored to ensure regular attendance and participation in class.

2. The management of Almajiri Integrated Model School should lay more emphasis on the use of English language as the language of communication within the school environment. This will not only encourage the students to speak English language fluently but would also assist them in the understanding of other subject taught in the school.

\section{References}

Auwal, N.M (1992). Almajiri: A degeneration social institution. National Commission for Mass Literacy Adult and Non-Formal Education. Lagos: Valid Impression Services.

Bunza, U. B. (2009). Policy and situation analysis on the integration of Qur'anic with modern education in North-West zone of Nigeria. Unpublished Ph.D. Thesis. Faculty of Education \& Extension Services, UDU, Sokoto.

Dahiru, N. M. (2011). Reforming the Qur'anic school system: Options and strategies. Muslim Education Summit, National Commission for Nomadic Education, Kaduna. Retrieved 12/8/11: 22 am from http://www.uimga.org

Federal Republic of Nigeria (2004). NationalPolicy on Education. Yaba NERD.

Mahuta, G. A. (2009). Possible strategies for the integration of private islamiyyah education with modern education in order to attain education for all (EFA), under the Sokoto state UBE policy. Al.nadah Journal of Islamic Heritage, 6(1,2), 129-145.

Mubarak, M., Bargaja I. M., Aishatu. M. A., Hauwau A. A., \& Shafa'atu. U.T. (2012). Problems and prospects of Integrated Almajiri Education in Sokoto State. An undergraduate project submitted to the Department of 
Science and Vocational Education, Faculty of Education and Extension Services, Usmanu Danfodiyo University, Sokoto.

Njoku; J.N., \& Idoko; V. N. (2012). Attitude of the girl-child to school and its effect on her academic performance. African Journal of Allied Education, 6(2).

Salawu A. A. (1991). Relationship between adolescent self concept, perception of parents' behaviour and their academic achievement. Unpublished Ph.D Thesis, University of Ilorin, Ilorin.

Sule, A. K. (2002). The Almajiri phenomenon study of the youth in traditional Qur'anic scholarship in Northern Nigeria., Nigeria. The humanities Journal, 1(1), 27-47. 